\title{
PENGARUH MODEL PEMBELAJARAN INKUIRI TERBIMBING TERHADAP PENGUASAAN KONSEP DAN KEMAMPUAN BERPIKIR KRITIS FISIKA PESERTA DIDIK KELAS X SMAN 1 KURIPAN TAHUN AJARAN 2017/2018
}

\author{
Suci Yeritia, Wahyudi, Satutik Rahayu \\ Program Studi Pendidikan Fisika \\ FKIP, Universitas Mataram \\ Jalan Majapahit No. 62, Mataram \\ Email: suci26yeritia@gmail.com
}

\begin{abstract}
This research aimed to examine the effect of guided inquiry learning model toward concept mastery and critical thinking ability of physics of X grade students of SMAN 1 Kuripan in academic year 2017/2018. This research was an experimental research with post test only control group design. The population of this research was X MIA students consicted of 3 classes with the total number of the students was 30 for each class. The sample was chosen using cluster random sampling technique. Technique of collecting data of the mastery concept and critical thinking ability using essay test. Gained data was analyzed using manova test. The result of hypotesis test showed $F_{\text {count }}>F_{\text {table }}$, so it was concluded that there was an effect of guided inquiry learning wodel on the mastery of concept and critical thinking ability of physics of $X$ grade students of SMAN 1 Kuripan in academic year $2017 / 2018$.
\end{abstract}

Keywords: Guided Inquiry Model, Concept Mastery, Critical Thinking Ability

\section{PENDAHULUAN}

Ilmu pengetahuan alam (IPA) merupakan ilmu yang berkaitan dengan cara mencari tahu tentang alam secara sistematis sehingga IPA bukan hanya penguasaan kumpulan pengetahuan berupa fakta-fakta, konsepkonsep, atau prinsip-prinsip saja, tetapi juga merupakan suatu proses penemuan (Fitriani et al. 2017). Fisika merupakan salah satu cabang ilmu pengetahuan alam yang terdiri dari konsep, prinsip, teori dan atau hukum terkait dengan gejala-gejala alam yang ada (Helmi et al. 2017). Pembelajaran fisika harus diarahkan untuk mencari tahu dan berbuat sehingga dapat membantu peserta didik untuk memperoleh penguasaan yang lebih mendalam, oleh sebab itu, pembelajaran fisika harus menekankan pada pemberian pengalaman langsung dan berpusat pada siswa. Dahar (2011), menyebutkan bahwa belajar konsep merupakan hasil utama pendidikan. Dengan demikian, perlu dikembangkan tingkat penguasaan konsep peserta didik dalam pembelajaran fisika. Selain penguasaan konsep, tujuan pembelajaran fisika adalah mengembangkan kemampuan berpikir. Kemampuan berpikir merupakan dasar dalam suatu proses pembelajaran (Heong et al. 2011). Berpikir kritis memungkinkan peserta didik untuk menganalisis pikirannya dalam menentukan pilihan dan menarik kesimpulan dengan cerdas. Berpikir kritis adalah sebuah proses mental, tujuannya untuk membuat keputusan yang logis tentang apa yang harus diyakini dan apa yang harus dilakukan. Dengan demikian, proses mental ini akan memunculkan kemampuan berpikir kritis peserta didik untuk dapat menguasai fisika secara mendalam. Adapun indikator berpikir kritis yang digunakan sebanyak lima yaitu klarifikasi dasar, keputusan dasar, inferensi, penjelasan lebih lanjut, menalar dan pengintegrasian (Latifa et al. 2017). Berdasarkan hasil observasi yang 
peneliti lakukan di SMAN 1 Kuripan melalui wawancara dengan salah seorang guru dan beberapa peserta didik, bahwa metode yang digunakan dalam pembelajaran fisika yaitu metode ceramah, metode diskusi, dan metode eksperimen. Namun, metode yang lebih sering digunakan adalah metode ceramah, di mana dalam proses pembelajaran masih didominasi oleh peran aktif guru dan peserta didik masih kurang aktif, dengan kata lain pembelajaran masih bersifat teacher center bukan student center. Hal ini yang memberikan dampak pada penguasaan konsep dan kemampuan berpikir kritis fisika peserta didik rendah.

Menyikapi permasalahan tersebut, salah satu pembelajaran yang dapat membantu siswa untuk mengembangkan penguasaan konsep dan kemampuan berpikir kritisnya adalah pembelajaran inkuiri terbimbing. Inkuiri terbimbing adalah model pembelajaran di mana peserta didik bekerja untuk menemukan jawaban terhadap masalah yang dikemukakan oleh guru dengan bimbingan yang intensif (Anam, 2015). Dengan kata lain, pembelajaran inkuiri terbimbing mampu mengembangkan keinginan dan motivasi peserta didik untuk mempelajari prinsip dan konsep fisika. Pembelajaran inkuiri terbimbing dapat membantu peserta didik dalam mengembangkan tanggung jawab individu dan kemampuan memahami konsep (Sayyadi et al. 2016)

Pembelajaran inkuiri memiliki beberapa tahapan yakni menetapkan masalah, merumuskan hiposesis, merancang percobaan, melakukan percobaan/eksperimen, mengolah dan menganalisis data, hingga membuat kesimpulan (Wahyuni et al. 2016). Model pembelajaran ini akan menantang siswa untuk senantiasa aktif selama proses pembelajaran sekaligus mendorong peserta didik untuk mengoptimalkan keterampilan dan kemampuannya. Peran siswa dalam model pembelajaran inkuiri ini yaitu mencari dan menemukan sendiri materi pelajaran, sedangkan guru berperan sebagai fasilitator dan pembimbing peserta didik untuk belajar. Pada model pembelajaran inkuiri terbimbing, guru memberikan bimbingan dan petunjuk bagi peserta didik selama kegiatan pembelajaran. Dengan demikian, pembelajaran inkuiri ini dapat membantu siswa untuk mengonstruksi konsep fisika yang dipelajari melalui proses berpikir. Hal ini telah dibuktikan oleh penelitian Kurniawati et al. (2013), bahwa salah satu pembelajaran yang dapat membantu peserta didik untuk mengembangkan penguasaan konsep dan kemampuan berpikir kritis peserta didik adalah pembelajaran inkuiri terbimbing.

\section{METODE PENELITIAN}

Penelitian eksperimen ini menggunakan posttest only control group design. Penelitian ini melibatkan variabel bebas, yaitu model pembelajaran inkuiri terbimbing dan variabel terikat yaitu penguasaan konsep dan kemampuan berpikir kritis, serta variabel kontrol yaitu guru yang mengajar, waktu dan bahan ajar. Penelitian ini dilakukan di SMA Negeri 1 Kuripan dengan teknik pengambilan sampel yaitu cluster random. Sampel penelitian terdiri dari dua kelas yaitu peserta didik kelas X MIA 2 sebagai kelas eksperimen dan X MIA 3 sebagai kelas kontrol dengan jumlah peserta didik masing-masing 30 orang. Instrumen yang digunakan untuk mengukur kedua variabel terikat dalam penelitian ini berbentuk tes uraian yaitu 8 soal untuk penguasaan konsep dan 6 soal untuk kemampuan berpikir kritis. Uji analisis data menggunakan uji manova dengan taraf signifikan $5 \%$.

\section{HASIL DAN PEMBAHASAN}

Penelitian ini bertujuan untuk mendeskripsikan pengaruh model 
pembelajaran inkuiri terbimbing terhadap penguasaan konsep dan kemampuan berpikir kritis fisika peserta didik kelas X SMAN 1 Kuripan tahun ajaran 2017/2018. Data yang diperoleh merupakan nilai tes akhir yang dilakukan pada kelas eksperimen dan kontrol.

Berdasarkan hasil penelitian untuk tes penguasaan konsep, diperoleh skor rata-rata tiap item soal peserta didik kelas eksperimen lebih tinggi dibandingkan kelas kontrol. Skor rata-rata terendah peserta didik kelas eksperimen maupun kelas kontrol terdapat pada item soal nomor 7. Item soal nomor 7 membahas tentang bagaimana menyelesaikan persoalan berdasarkan tabel yang sudah disediakan. Penguasaan konsep peserta didik kelas eksperimen tergolong baik karena untuk item soal nomor 1 sampai dengan nomor 5, skor rata-rata yang diperoleh berkisar antara 4,2 sampai 4,9. Skor rata-rata tiap item untuk kelas kontrol tergolong cukup baik yaitu berkisar antara 3,3 sampai 4,1 untuk item soal nomor 1 sampai 6. Item soal nomor 7 masih tergolong rendah, sama halnya dengan peserta didik kelas eksperimen. Hasil ini menunjukkan peserta didik kedua kelas masih kurang mampu dalam menyelesaikan persoalan yang berkaitan dengan persamaan atau rumus-rumus. Meskipun demikian, skor rata-rata kelas eksperimen lebih tinggi dibandingkan kelas kontrol. Hal ini menunjukkan bahwa ada pengaruh model pembelajaran inkuiri terbimbing yang diterapkan di kelas eksperimen.

Adapun nilai yang diperoleh masingmasing kelas untuk tes penguasaan konsep dapat dilihat pada Gambar 1 berikut. Gambar 1 menunjukan bahwa hasil tes akhir untuk peserta didik kelas eksperimen memiliki nilai tertinggi, nilai terendah dan nilai rata-rata lebih tinggi dibandingkan kelas kontrol. Penguasaan konsep sangat penting dimiliki oleh setiap peserta didik setelah melakukan pembelajaran karena dapat digunakan untuk menyelesaikan suatu permasalahan yang berkaitan dengan konsep yang dimiliki oleh peserta didik.

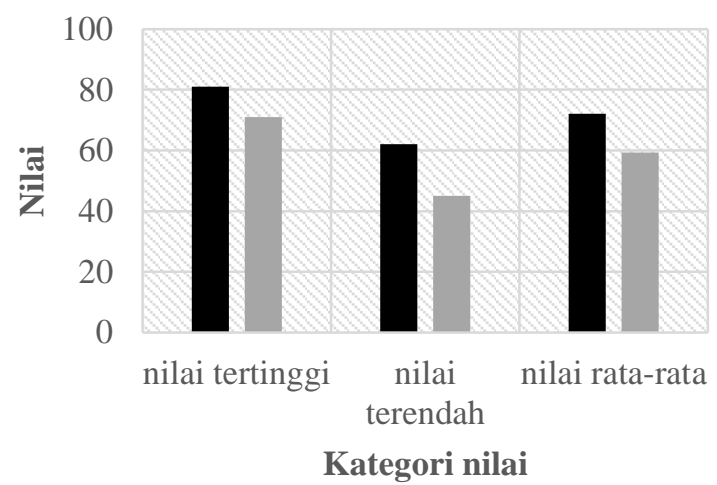

Kelas eksperimen $\square$ Kelas kontrol

Gambar 1. Hasil Tes Akhir Pengusaan Konsep Fisika Peserta Didik

Penguasaan konsep oleh peserta didik tidak hanya pada mengenal sebuah konsep tetapi peserta didik dapat menghubungkan antara satu konsep dengan konsep lainnya dalam berbagai situasi. Penerapan pembelajaran inkuiri terbimbing, peserta didik yang aktif dan terlibat langsung dalam eksperimen akan lebih mendalami konsep dengan membuat hubungan antara bagianbagian informasi yang saling terpisah untuk menjadi gambaran yang terperinci. Peserta didik yang belajar melalui pembelajaran inkuiri terbimbing memiliki dampak jangka panjang pada penguasaan konsep-konsep fisika. Diterapkannya model pembelajaran inkuiri, peserta didik lebih tertarik pada pembelajaran yang diajarkan karena peserta didik mendapatkan pengalaman secara langsung karena dalam proses pembelajaran dengan model inkuiri terbimbing, peserta didik belajar dari permasalahan yang diberikan oleh guru, kemudian membuat hipotesis, mencari informasi yang berkaitan dengan permasalah tersebut melalui eksperimen untuk memperoleh data, selanjutnya, mengolah data kemudian peserta didik dapat menarik kesimpulan mengenai masalah yang diberikan berdasarkan eksperimen. Hasil penelitian ini juga sesuai 
dengan penelitian yang terlebih dahulu dilakukan oleh Subahiyah et al. 2013 yaitu, model pembelajaran inkuiri terbimbing yang diterapkan dalam penelitian terbukti dapat meningkatkan penguasaan konsep peserta didik. Hal ini disebabkan karena seluruh rangkaian kegiatan pembelajaran dengan model inkuiri terbimbing lebih menekankan pada aktivitas peserta didik secara maksimal melalui kegiatan ilmiah untuk mencari dan menemukan sendiri konsep-konsep yang dipelajari, sehingga peserta didik akan lebih mudah memahami konsep-konsep yang rumit dan abstrak karena disertai dengan pengalaman nyata dan terhindar dari cara-cara belajar tradisional (menghafal). Sementara untuk data hasil tes akhir kemampuan berpikir kritis, dapat dilihat pada Gambar 2.

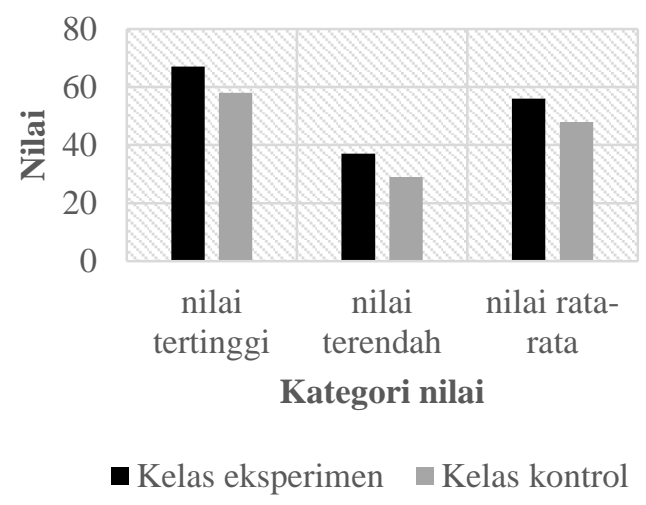

Gambar 2. Hasil Tes Akhir Kemampuan Berpikir Kritis Peserta Didik

Gambar 2 menunjukan bahwa hasil tes akhir peserta didik kelas eksperimen memiliki nilai tertinggi, nilai terendah dan nilai rata-rata kelas lebih tinggi dibandingkan kelas kontrol. Adapun deskripsi skor rata-rata hasil pengukuran data akhir kemampuan berpikir kritis peserta didik tiap indikator untuk kelas eksperimen dan kelas kontrol dapat dilihat pada Gambar 3 berikut.

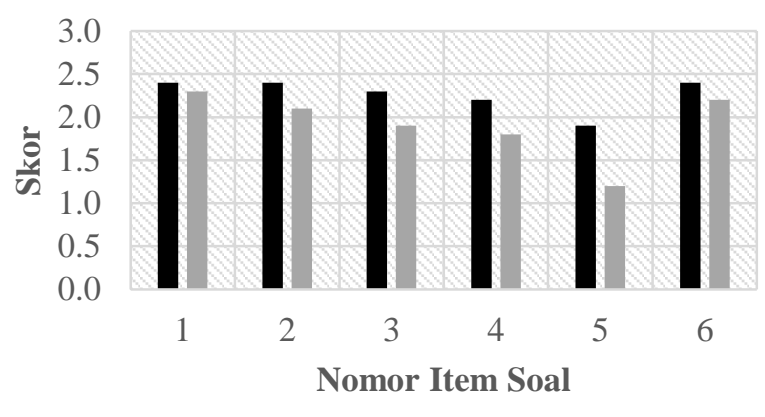

- Kelas eksperimen Kelas kontrol

Gambar 3. Skor Rata-rata Tiap Item Soal Kemampuan Berpikir Kritis Kelas Eksperimen dan Kelas Kontrol

Hasil penelitian untuk instrumen kemampuan berpikir kritis, indikator pertama yaitu klarifikasi dasar, berkriteria kurang kritis pada kelas eksperimen dengan nilai 52,5 dan untuk kelas kontrol berkriteria sangat kurang kritis dengan nilai 42,5. Hasil ini menunjukkan perbedaan yang signifikan antara kedua kelas, hal ini diakibatkan karena salah satu tahap model pembelajaran inkuiri terbimbing yang digunakan pada kelas eksperimen mendukung indikator tersebut. Tahap yang dimaksud adalah tahap menyajikan masalah. Fase ini peserta didik menyampaikan pendapat mengenai pengetahuan yang telah didapatkan sebelumnya. Melalui fase ini mereka dituntut untuk dapat menganalisis pendapat yang disampaikan dengan cara mengidentifikasi alasan mengenai konsep tertentu.

Indikator kemampuan berpikir kritis selanjutnya yaitu keputusan dasar berkriteria kurang kritis pada kedua kelas dengan masingmasing nilai yang didapatkan yaitu 55 pada kelas eksperimen dan 45 pada kelas kontrol. Meskipun berkategori sama, namun terdapat perbedaan nilai yang disebabkan karena pada kelas eksperimen informasi atau pengetahuan yang didapatkan dicari sendiri dengan menggunakan berbagai sumber, lain halnya dengan kelas kontrol yang diberikan umpan terlebih dahulu oleh guru sebelum bekerja mandiri. 
Indikator yang ketiga yaitu inferensi yang berkriteria kurang kritis pada kedua kelas dan nilai pada kelas eksperimen yaitu 57,5 dan 47,5 pada kelas kontrol. Perbedaan nilai kelas eksperimen dan kelas kontrol yang diperoleh meskipun dalam kategori yang sama, terjadi karena pada setiap pertemuan yang telah dirancang dengan percobaan peserta didik diarahkan untuk melakukan inferensi. Inferensi yaitu membuat simpulan berdasarkan sesuatu yang dapat diukur dan diamati langsung. Begitu juga pada kelas kontrol walaupun tidak melakukan inferensi namun mereka melakukan kegiatan menyimpulkan pada akhir proses pembelajaran, sehingga dapat dikatakan bahwa pembiasaan pada proses pembelajaran memberikan pengaruh terhadap indikator ini.

Indikator yang keempat yakni penjelasan lebih lanjut pada kelas eksperimen dan kelas kontrol berturut-turut nilainya sebesar 60 dan 52,5 yang berkategori kurang kritis. Meskipun dalam kategori yang sama, terdapat perbedaan nilai yang signifikan antara kelas eksperimen dan kelas kontrol. Hal ini disebabkan karena, salah satu tahap model pembelajaran pada kelas ekperimen berpengaruh terhadap hasil yang diperoleh. Tahap tersebut ialah menyimpulkan. Secara tidak langsung peserta didik dilatih untuk membuat bentuk definisi sesuai dengan LKPD yang sudah disiapkan.

Indikator yang kelima yaitu menalar dan pengintegrasian merupakan indikator yang paling sedikit perbedaan nilai antara kelas eksperimen dan kelas kontrol. Nilai rata-rata kelas eksperimen yaitu sebesar 60 berada pada kriteria kurang kritis. Begitu juga halnya dengan kelas kontrol yang memiliki kriteria kurang kritis dengan nilai sebesar 57,5. Perbedaan nilai yang sangat rendah disebabkan karena kurangnya penalaran yang diintegrasikan dengan pemikiran pengandaian pada proses diskusi. Rangkaian pembelajaran yang diterapkan pada kelas eksperimen menunjukkan terdapat proses untuk melatih keterampilan berpikir kritis karena keterampilan berpikir kritis tidak akan berkembang apabila tidak dilatih. Hasil penelitian ini sesuai dengan penelitian yang telah dilakukan Nur'Azizah et al. 2016 dan Kristanto et al. 2015, dalam penelitiannya menyatakan bahwa, model pembelajaran inkuiri terbimbing dapat meningkatkan kemampuan berpikir kritis peserta didik.

Berdasarkan data tes akhir yang diberikan pada peserta didik kelas eksperimen dan kelas kontrol, nilai rata-rata penguasaan konsep dan kemampuan berpikir kritis peserta didik kelas eksperimen lebih tinggi dibandingkan dengan nilai rata-rata penguasaan konsep dan kemampuan berpikir kritis peserta didik kelas kontrol. Sementara dari hasil Uji Manova, diperoleh $F_{\text {hitung }}>F_{\text {tabel }}$ yaitu 27,93 > 3,159 . Hasil penelitian ini menunjukkan bahwa terdapat pengaruh model pembelajaran inkuiri terbimbing terhadap penguasaan konsep dan kemampuan berpikir kritis peserta didik kelas X SMAN 1 Kuripan Tahun Ajaran 2017/2018.

Perbedaan penguasaan konsep dan kemampuan berpikir kritis antara peserta didik kelas eksperimen dan kelas kontrol disebabkan oleh diterapkannya model pembelajaran inkuiri terbimbing. Penerapan model pembelajaran inkuiri terbimbing, peserta didik aktif bekerja secara berkelompok, melakukan diskusi antara satu dengan yang lainnya, sementara guru bertugas membimbing peserta didik selama proses pembelajaran berlangsung. Hal ini berarti, guru pada model pembelajaran ini berperan sebagai fasilitator, yaitu lebih menekankan pada pemberian arahan, sedangkan peserta didik bersama kelompok masing-masing berusaha dalam menemukan jawaban dan informasi mengenai permasalahan melalui serangkaian penyelidikan. Hal ini sesuai dengan pernyataan Anam (2015:17), yang mengatakan bahwa, inkuiri terbimbing adalah model pembelajaran di mana siswa bekerja untuk menemukan jawaban terhadap 
masalah yang dikemukakan oleh guru dengan bimbingan yang intensif. Proses pembelajaran inkuiri terbimbing, guru meluangkan banyak waktu untuk berinteraksi dengan peserta didik tetapi tidak banyak menunjukkan atau membantu peserta didik dalam merumuskan jawaban terhadap pertanyaan. Hasil penelitian ini sejalan dengan hasil penelitian yang telah dilakukan oleh Kurniawati et al. (2014) yang menyatakan bahwa, model pembelajaran inkuiri terbimbing dapat mengembangkan penguasaan konsep serta kemampuan berpikir kritis peserta didik. Kemampuan berpikir kritis peserta didik akan berimplikasi pada penguasaan konsep peserta didik. Kemampuan berpikir kritis peserta yang tinggi akan memiliki penguasaan konsep yang tinggi pula. Nur'Azizah et al. 2016 dan Kristanto et al. 2015, dalam penelitiannya menyatakan bahwa, model pembelajaran inkuiri terbimbing dapat meningkatkan kemampuan berpikir kritis peserta didik dibandingkan dengan pembelajaran konvensional. Penerapan pembelajaran inkuiri terbimbing, peserta didik diberi kesempatan untuk terlebih dahulu menduga hal-hal yang akan terjadi, membuktikan dugaan-dugaan yang diajukan melalui kegiatan percobaan bersama kelompok, saling mengkomunikasikan hasil percobaan yang diperoleh masing-masing kelompok, memecahkan masalah dengan memutuskan hasil percobaan yang relevan dengan permasalahan yang diajukan mengakibatkan kemampuan berpikir kritis peserta didik dapat meningkat. Sementara itu, penggunaan model pembelajaran konvensional, proses pembelajarannya lebih menekankan pada proses penyampaian materi secara verbal dari seorang guru kepada sekelompok peserta didik dengan maksud agar peserta didik dapat menguasai materi pembelajaran dengan optimal.

Pembelajaran fisika akan lebih maksimal jika pembelajaran dilakukan secara bermakna dan mengoptimalkan kegiatan yang dapat meningkatkan penguasaan konsep-konsep fisika dan kemampuan berpikir kritis peserta didik dalam proses pembelajaran di kelas. Tercapainya hal yang demikian, diperlukannya pemilihan model pembelajaran yang sesuai dengan karakteristik materi yang diajarkan pada peserta didik serta penggunaan bahan ajar yang menunjang kegiatan pembelajaran.

\section{PENUTUP}

Berdasarkan hasil penelitian, penguasaan konsep dan kemampuan berpikir kritis fisika peserta didik kelas eksperimen lebih tinggi dibandingkan kelas kontrol sehingga dapat disimpulkan bahwa, ada pengaruh model pembelajaran inkuiri terbimbing terhadap penguasaan konsep dan kemampuan berpikir kritis peserta didik kelas X SMAN 1 Kuripan tahun ajaran 2017/2018.

\section{REFERENSI}

Anam, K. 2015. Pembelajaran Berbasis Inkuiri: Metode dan Aplikasi. Yogyakarta: Pustaka Pelajar.

Dahar, W. R. 2011. Teori-teori Belajar Belajar dan Pembelajaran. Bandung: Erlangga.

Fitriani, N., Gunawan, Sutrio. 2017. Berpikir Kreatif dalam Fisika dengan Pembelajaran Conceptual Understanding Procedures (CUPs) berbantuan LKPD. Jurnal Pendidikan Fisika dan Teknologi, 3(1), 24-33.

Helmi, F., Rokhmat, J., 'Ardhuha, J. 2017. Pengaruh Pendekatan Berpikir Kausalitik Ber-Scaffolding Tipe 2B Termodifikasi berbantuan Lks terhadap Kemampuan Pemecahan Masalah Fluida Dinamis Siswa. Jurnal Pendidikan Fisika dan Teknologi. 3(1), 68-75.

Heong, Y. M., Yunos, J. M., Hassan, R. B., Othman, W. B., Kiong, T. T. 2011. The Perception of The Level of Higher Order Thinking Skills among Technical 
Education Students. International Conference on Social Science and Humanity journal. 5(2), 281-285.

Kristanto, Y. E., 2015. Pengaruh Model Pembelajaran Inkuiri Terbimbing terhadap Kemampuan Berpikir Kritis dan Hasil Belajar IPA Siswa Kelas VII SMP. Jurnal Pendidikan dan Pembelajaran. 22(2).

Kurniawati, I. D., Wartono, Diantoro, M. 2013. Pengaruh Pembelajaran Inkuiri Terbimbing Integrasi Peer Instruction terhadap Penguasaan Konsep dan Kemampuan Berpikir Kritis Siswa. Jurnal Pendidikan Fisika Indonesia. 10(1), 36-46.

Latifa, B. R., Verawati, N. N. S. P., Harjono, A. 2017. Pengaruh Model Learning Cycle 5E (Engage, Explore, Explain, Elaboration, \& Evaluate) terhadap Kemampuan Berpikir Kritis Peserta Didik Kelas X MAN 1 Mataram. Jurnal Pendidikan Fisika dan Teknologi, 3(1), 61-67.

Nur'Azizah, H., Jayadinata, A. P., Gusrayani, D. 2016. Pengaruh Model Pembelajaran Inkuiri Terbimbing terhadap Kemampuan Berpikir Kritis Siswa Pada Materi Energi Bunyi. Jurnal Pena Ilmiah. 1(1), 51-60.

Sayyadi, M., Hidayat, A., Muhardjito. 2016. Pengaruh Strategi Pembelajaran Inkuiri Terbimbing dan terhadap Kemampuan Pemecahan Masalah Fisika pada Materi Suhu dan Kalor dilihat dari Kemampuan Awal Siswa. Jurnal Inspirasi Pendidikan Universitas Kanjuruhan Malang, 6(2), 866-875.

Subahiyah, Marhaeni A. A. I. N., Suastra, I. W. 2013. Pengaruh Model Pembelajaran Inkuiri Terbimbing terhadap Keterampilan Proses Sains dan Penguasaan Konsep IPA Siswa Kelas V Gugus 03 Wanasaba Lombok Timur. $e$ Journal Program Pascasarjana Universitas Pendidikan Ganesha. Vol 3.
Wahyuni, R., Hikmawati, Taufik, M. 2016. Pengaruh Model Pembelajaran Inkuiri Terbimbing dengan Metode Eksperimen terhadap Hasil Belajar Fisika Siswa Kelas XI IPA SMAN 2 Mataram Tahun Pelajaran 2016/2017. Jurnal Pendidikan Fisika dan Teknologi, 2(4), 164-169. 